\title{
ВИПАДОК ПЕРВИННОГО АЛЬДОСТЕРОНІЗМУ
}

Вищий державний навчальний заклад України «Буковинський державний медичний університет», м. Чернівці

Резюме. Наведено випадок первинного альдостеронізму, який клінічно проявився стабільною резистентною артеріальною гіпертензією і м'язовим синдромом. Захворювання зумовлене двобічною вузликовою гіперплазією кори надниркових залоз.
Ключові слова: артеріальна гіпертензія, гіперплазія надниркових залоз, альдостерон, гіпокаліємія, верошпірон.
Первинний альдостеронізм (ПА, синдром Конна) - група станів, при яких продукція альдостерону клубочковою зоною кори надниркових залоз (Н3) є непропорційно високою, повністю або частково автономною [1]. ПА - одне з найпоширеніших захворювань НЗ та найчастіша причина ендокринної артеріальної гіпертензії (АГ). Приблизно в 30-40 \% випадків захворювання спричиняється однобічною солітарною аденомою (альдостеромою), у 60-70 \% хворих має місце двобічна дифузна чи вузликова гіперплазія кори Н3 $[1,2,7]$. Частота ПА становить 6-15 \% популяції хворих на $А Г$, а з-поміж пацієнтів із резистентною АГ - $20 \%$ [3] .

Роль альдостерону в механізмах розвитку АГ - пригнічення синтезу реніну, затримка натрію, збільшення об'єму циркулюючої крові, акумуляція натрію в судинній стінці із підвищенням судинного опору і зростання іiі чутливості до вазоконстриктурних стимулів, розвиток низькоренінової гіпертензії - доповнилися останнім часом даними щодо прозапальної, профібролітичної, прооксидативної дії згаданого гормону. Гіперальдостеронемія асоційована з самостійним, незалежним від АГ, підвищеним ризиком розвитку кардіоваскулярних ускладнень $[1,2,4,5,6]$. Гіпокаліємія веде до дистрофічних змін нервових волокон і розвитку м'язового синдрому та нефропатії [2].

Найінформаційнішим скринінговим тестом визнане наростаюче співвідношення альдостерону/реніну плазми крові. Наявність позитивного співвідношення і за умови забору крові після перебування пацієнта у вертикальному положенні більше 20-25 хв із 90\% вірогідністю свідчить на користь ПА [3].

Наводимо наше спостереження.

Хвора П., 55 років, направлена кардіологом у зв'язку з резистентною АГ, яка іноді набувала кризового характеру. Привертали увагу скарги на спрагу, часте сечовипускання, наростаючу м'язову слабкість, парестезії в нижніх кінцівках.

Об'єктивно. Статура гіперстенічна. Серцева діяльність аритмічна, 60/хв. Серцева тупість зміщена вліво на 2 см, акцент II тону над аортою. АТ зберігався на рівні 180-200/100-110 мм рт. ст.

ЕКГ: ЧСС - 62/хв, ознаки гіпертрофії лівого шлуночка серця 3 перезавантаженням, екстрасистолія. Очне дно: гіпертонічна ретинопатія.
Клінічні аналізи крові і сечі без змін. Глюкоза крові - 5,8 ммоль/л. Альдостерон плазми крові - 265 пг/мл (норма 10-165), активний ренін - 2,1 пг/мл (норма 3,3-31,7), натрій - 198 ммоль/л (норма - 135-148), калій - 2,4 ммоль/л (норма 3,5-5,1).

МРТ заочеревинного простору: двобічна вузликова гіперплазія Н3, вузлики розміром 3-5-6 мм підвищеної щільності. Регіонарні лімфовузли не збільшені.

Діагноз: первинний альдостеронізм, двобічна вузликова гіперплазія надниркових залоз, артеріальна гіпертензія.

До комплексу лікування, призначеного кардіологом, рекомендовано включити верошпірон 200-150 мг/добу. Доза підбиралась методом титрування кожні два тижні під контролем АТ і рівня калію крові, починаючи 325 мг. Через три місяці загальний стан здоров'я хворої покращився, прояви м'язового синдрому зникли. Прослідковується тенденція до нормалізації мінерального обміну та рівня альдостерону крові. АТ у межах 150-140/95-80 мм рт.ст.

\section{Висновок}

Пацієнти 3 артеріальною гіпертензією, насамперед із резистентною формою та ускладненим перебігом, підлягають обстеженню на предмет виключення гіпертензії ендокринного генезу, у першу чергу - первинного альдостеронізму.

\section{Коментарій}

Резистентна артеріальна гіпертензія, порушення мінерального обміну (гіпернатріємія, гіпокальціємія), високий рівень альдостерону (верошпірону) за низького вмісту реніну крові дали аргументовану підставу запідозрити первинний альдостеронізм. Діагноз верифіковано МРТ Н3. Включення в комплекс терапевтичних засобів антагоністу альдостерону призвело до суттєвого зниження АТ. Калійзберігаючі діуретики можуть бути корисною альтернативою [1]. Хворим на ПА, зумовленим однобічним процесом (альдостерома, однобічна гіперплазія), показана лапароскопічна адреналектомія [2]. У випадку вторинного альдостеронізму, котрий розвивається як ускладнення деяких захворювань серцевосудинної системи, нирок, печінки, активність реніну суттєво зростає. 


\section{Література}

1. Рекомендації української асоціації кардіологів, української асоціації ендокринних хірургів, асоціації нефрологів України з диференційної діагностики артеріальних гіпертензій 2014p. // Міжнар. ендокринол. ж. 2014. - № 8 (64). - С. 125-154.

2. Рибаков С.Й. Пухлини кіркової речовини надниркових залоз / С.Й. Рибаков // Ендокринологія; за ред А.С.Єфімова. - К.: Вища шк., 2004. - С. 299-329.

3. Черенько С.М. Сучасні підходи до діагностики, терапевтичного та хірургічного лікування первинного альдостеронізму / С.M. Черенько, О.С. Ларін, Л.В. Щекатурова // Львів. мед.часопис. - 2006. - Т. 17, № 2. - C. 76-80.

4. Young W.F. Minireview: Primary Aldosteronism Changing Concepts in Diagnosis and Treatment /
W.F. Young // Endocrinology. - 2003. - Vol. 144, № 6. P. 2208-2213.

5. Case Detection, Diagnosis, and Treatment of Patients with Primary Aldosteronism: An Endocrine Society Clinical Practice Guideline / Y.W. Funder, R.M. Carey, C. Fardella [et al.] // J.Clin.Endocr.Metab. - 2008. Vol. 93, № 9. - P. 3266-3281.

6. Primary hyperaldosteronism in essential hypertensives: prevalence, biochemical profile, and molecular biology / C.E. Fardella, L. Mosso, C.E. Gomes-Sanchez [et al.] // J. Clin. Endocrinol. Metab. - 2000. - Vol. 85. P. 1863-1867.

7. Rossi G.P. Surgically correctable hypertension caused by primary aldosteronism / G.P. Rossi // Best Pract. Res. Clin. Endocrinol. Metab. - 2006. - Vol. 20. - P. 385-400.

\section{СЛУЧАЙ ПЕРВИЧНОГО АЛЬДОСТЕРОНИЗМА}

\section{Р.П. Ляшук, П.М. Ляшук}

Резюме. Приведен случай первичного альдостеронизма, который клинически проявился стабильной резистентной артериальной гипертензией и мышечным синдромом. Заболевание обусловлено двухсторонней узелковой гиперплазией коры надпочечников.

Ключевые слова: артериальная гипертензия, гиперплазия надпочечников, альдостерон, гипокалиемия, верошпирон.

\section{A CASE OF PRIMARY ALDOSTERONISM}

\section{R.P. Lyashuk, P.M. Lyashuk}

Abstract. The paper deals with a case of primary aldosteronism, which declared itself clinically by stable resistant hypertension and muscle syndrome. The disease is caused by bilateral nodular hyperplasia of adrenal glands.

Key words: hypertension, hyperplasia of the adrenal glands, aldosterone, hypokaliemia, veroshpiron .

Higher State Educational Institution of Ukraine «Bukovinian State Medical University» (Chernivtsi)

Рецензент - проф. О.І. Волошин

Buk. Med. Herald. - 2016. - Vol. 20, № 3 (79). - P. 234-235

Надійшла до редакції 02.06.2016 року

C Р.П. Ляшук, П.М. Ляшук, 2016 